\title{
The middle and late Holocene Barrier Spit System at Vejers, Denmark: Structure and Development
}

\author{
SØREN TOFT NIELSEN, LARS B. CLEMMENSEN \& FRANK ANDREASEN
}

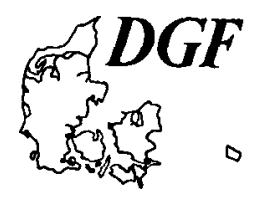

Nielsen, S. T., Clemmensen, L. B. \& Andreasen, F.: The middle and late Holocene
Barrier Spit System at Vejers, Denmark: Structure and Development. Bulletin of the
Geological Society of Denmark, Vol. 42, pp. 105-119. Copenhagen, 1995-10-31.
https://doi.org/10.37570/bgsd-1995-42-10

Georadar data $(72 \mathrm{~km})$ combined with borings and datings form the basis of a study of the three-dimensional build-up of the middle and late Holocene barrier spit system at Vejers, Denmark.

The georadar data reveal one barrier spit covering $15-20 \mathrm{~km}^{2}$, with an average thickness of approximately 10 meters. This barrier spit shows a ripartite build-up. At the base a shoal sand unit of well-sorted, fine- to medium-grained sand occurs. The overlying inter-val constitutes a barrier core unit, stretching from north to south, and composed of alterna-ting layers of westward dipping coarse sand- and gravel layers. At the top of these layers aeolian sand sheet and dune deposits occur. The barrier core unit is followed to the east by a back-barrier unit of fine- to medium-grained sand, with a varying content of silt and plant fragments. These deposits are also overlain by aeolian sediments. A second, smaller and more inland situated barrier spit occurs in the central and southern parts of the investigated area.

It appears that barrier spit formation took place in three main stages. The initial stage occurred between c. 6500 and c. 4000 B.P. (transgressive period). Barrier spit consolidation and rapid growth took place between c. 4000 B.P. and c. 1200 A.D. (early highstand period). Final development and large-scale dune formation took place after 1200 A.D. (highstand period).

The dominance of west-ward dipping strata in the spit deposits indicates consistent seaward progradation of the spit. The shape of the spit indicates southward growth. Apparently the spit formed under the influence of a strong southward directed littoral drift, but the overall alignment of the spit was controlled by swash processes.

S. T. Nielsen \& L. B. Clemmensen, Geological Institute, University of Copenhagen, Øster Voldgade 10,DK-1350 Copenhagen. K. F. Andreasen, Department of Geology and Geotechnical Engineering, Technical University, DK-2800 Lyngby. 23rd December 1994.

\section{Introduction}

The large-scale structure and genesis of the middle and late Holocene barrier spit system and related deposits in the Henne-Vejers area on the western coast of Jutland, Denmark, have been discussed in a number of papers (Jessen 1925; Jonassen 1957; Krog 1979; Odgaard 1985 and Suadicani 1985). In 1987 a georadar investigation was carried out in order to give the authorities a detailed insight into the distribution and quantity of gravel-rich sediments in the area. The cause was an application for reclamation of gravel in the area (Ribe Amtskommune, Miljøministeriet, Danmarks Geologiske Undersøgelse \& Skov- og Naturstyrelsen 1989). In 1991 and 1994 georadar mapping of the area was continued with improved equipment.

This gave us a unique opportunity to make detailed studies of the three-dimensional build-up of the Holo- cene marine deposits in the area, and to explain the depositional history of the barrier spit system in relation to sea-level and coastal dynamics.

\section{Geological setting}

The Henne-Vejers area is an approximately $60 \mathrm{~km}^{2}$ large coastal plain just north of the most western point, B1åvands Huk, on the western coast of Jutland (Figs 1 and 2). The area is delimited to the north and to the east by Varde Bakkeø (Bakkeø is a Danish term for a periglacially smoothed element of Pre-Weichselian landscape with sandur plains in between). The southern boundary is made up of Kallesmærsk Hede, and the North Sea forms a natural boundary to the west with a coast-parallel sediment transport directed south (Nielsen \& Nielsen 1990; Bartholdy \& Pejrup 1994). In- 


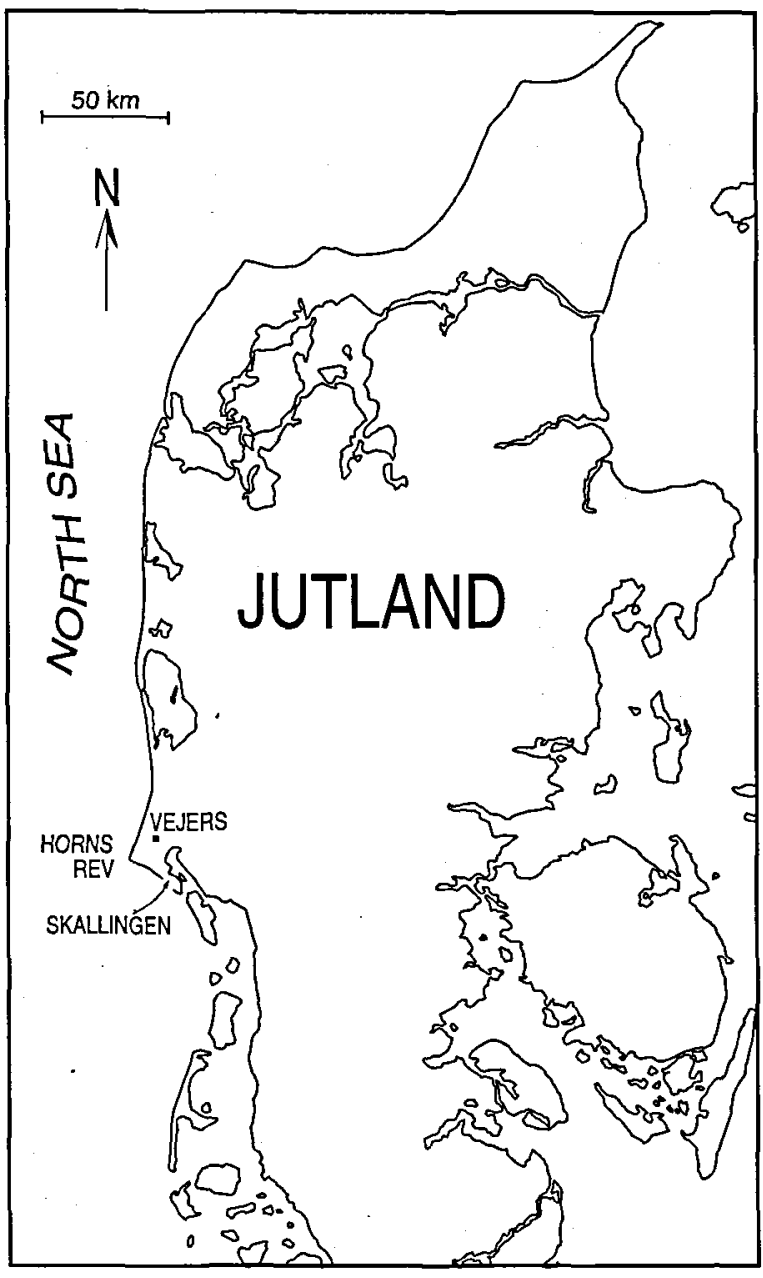

Fig. 1. Location of the study area at Vejers, western Jutland, Denmark.

side the area are two pronounced shallow water basins, the northern Fils $\varnothing$ basin, a former bay (Jonassen 1957; Krog 1979), now regulated by drainage; and the Langsa basin, around lake Langsø northwest of the village Grærup in the central part of the area (Fig. 2). The barrier spit deposits occur on top of early to middle Holocene well-sorted marine deposits, and are covered by aeolian deposits of late Holocene age (Clemmensen, Andreasen, Nielsen \& Sten, in press).

The main glacial element of the landscape in the Henne-Vejers area, Varde Bakke $\varnothing$, was formed after the Saalian glaciation (Jessen 1925). Drainage of the area took place in a westerly direction through the Fils $\varnothing$ basin into the North Sea. This drainage pattern may have been the incipient stage of the Henne Møllea stream, the western outlet of Fils $\varnothing$, and the Børsmose channel a southern outlet of the Fils $\varnothing$ basin. A marked north-south oriented cliff is found south of the Filsø basin. The cliff, called the Grærup Inland Cliff, is ap- proximately $5 \mathrm{~m}$ high and $4 \mathrm{~km}$ long. The cliff is situated on the western fringe of Varde Bakke $\phi$, and probably formed during the Littorina transgression maximum (c. 5000 B.P.).

The middle and late Holocene development of the Henne-Vejers area has been dealt with in various detail by Jessen (1925), Jonassen (1957), Krog (1979), Odgaard (1985) and Ribe Amtskommune et al. (1989). According to Jonassen (1957) the Fils $\emptyset$ basin was transformed into a bay at the end of the early Atlantic period (c. 6500 B.P.), while Krog (1979) meant that this event only took place in the beginning of the Atlantic period (c. 6000 B.P.). Subsequent rising relative sea-level in the North Sea area caused wave erosion of Varde Bakke $\varnothing$ and resulted in littoral sediment transport in a southern direction. This is similar to the present day sediment drift along the coast (Nielsen \& Nielsen 1990). A slower sea-level rise in the North Sea area around 5000 B.P., combined with an increasing rate of erosion, gradually transformed the Fils $\emptyset$ basin into a bay partly closed by southward growth of the main spit. During this period the Henne Mølleå stream outlet was still open, and a southern outlet (Børsmose

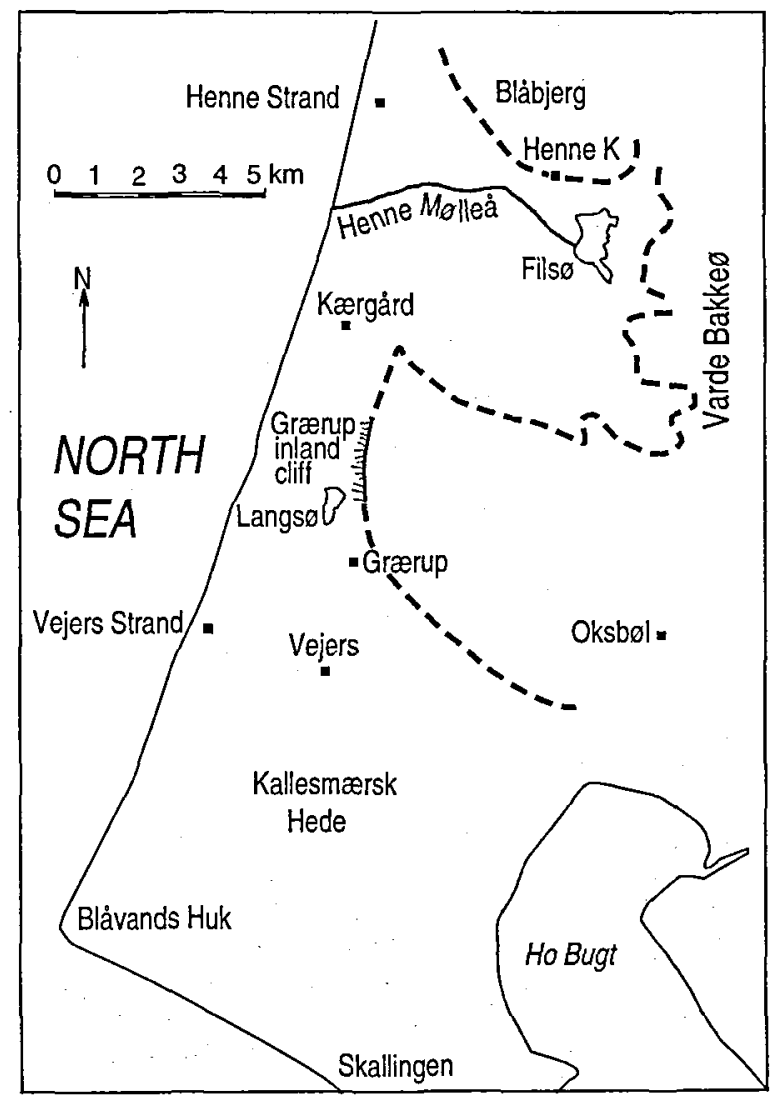

Fig. 2. Locality map of the investigated area at Vejers, western Jutland, Denmark. 
Fig. 3. Map showing location of georadar profiles and borings in the area of investigation.

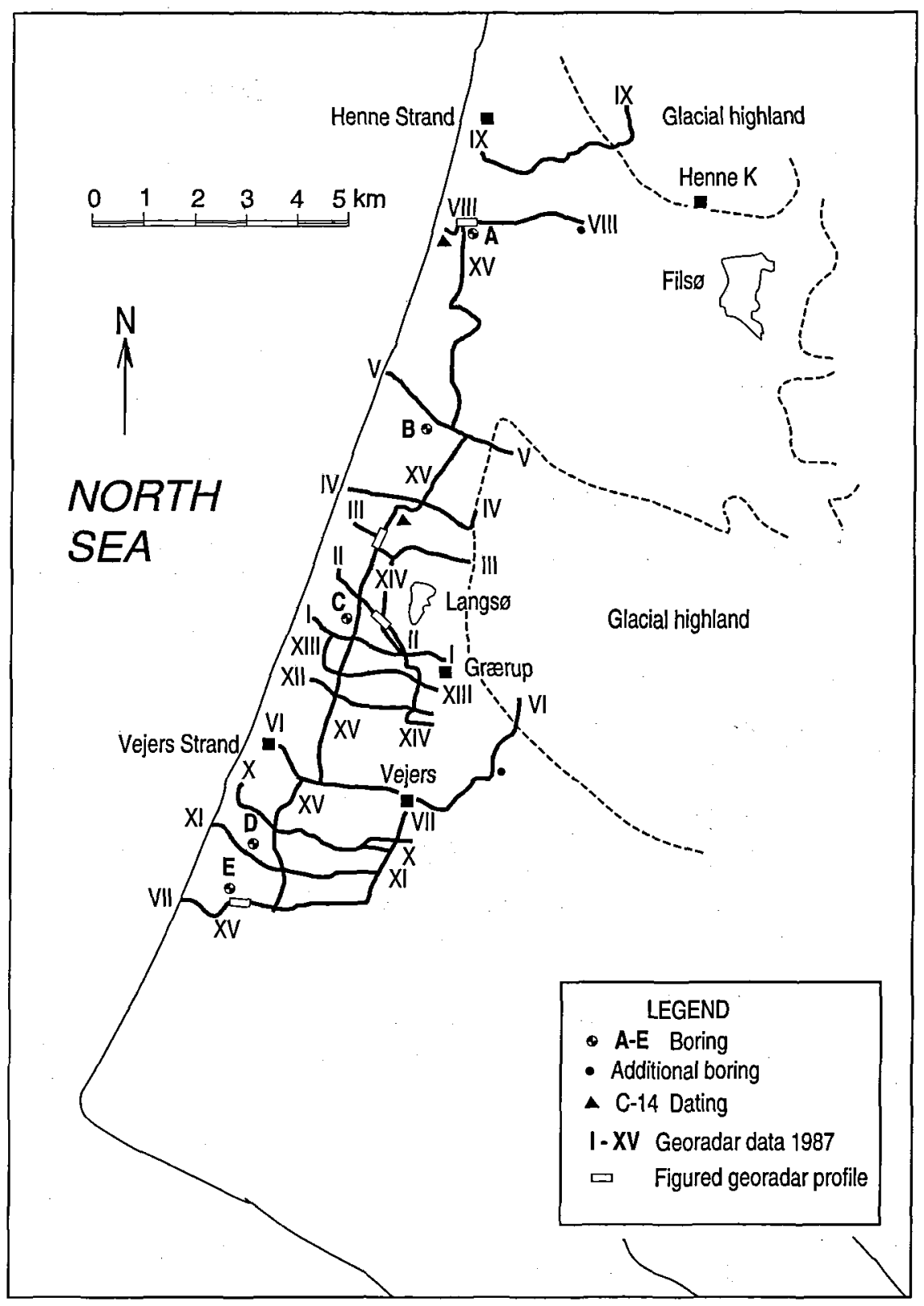

\section{Shoreline morphodynamics}

channel) is presumed to have existed. A continued southward barrier spit growthclosed the Fils $\varnothing$ bay completely, and this combined with sanding up of the Henne Mølleå stream outlet, probably by aeolian sand, lead to freshwater conditions and rising water table in the Fils $\varnothing$ basin. This change from marine to freshwater conditions in the Filsø basin was dated by pollen analysis to the end of the Atlantic period (c. 4000 B.P.) by Jonassen (1957), but to the end of the Subboreal period (c. 2500 B.P.) by Krog (1979). The water table rise in the Filsø lake began in middle/late Subboreal time and reached a maximum of $+7.2 \mathrm{~m}$ above sea level in Subatlantic time (after 3000 B.P.) (Jessen 1925).
The present shoreline between Henne Strand and Blåvands Huk (a linked barrier) is weakly curved and has an average orientation of $N 15^{\circ} \mathrm{E}$. The shoreline is wave dominated and the tidal range lies between 1 and 1.5 $\mathrm{m}$. The beach is wide and primarily composed of fine grained sand with an increasing content of gravel-size material towards the north. The resultant of onshore wind directions (year 1930-61) at Blåvands Huk has been calculated to $\mathrm{N} 100^{\circ} \mathrm{E}$. This indicates, that the resultant in this period is only slightly oblique to the coastline. As the coast is also affected by swells from the northwest (unlimited fetch) it appears, however, 


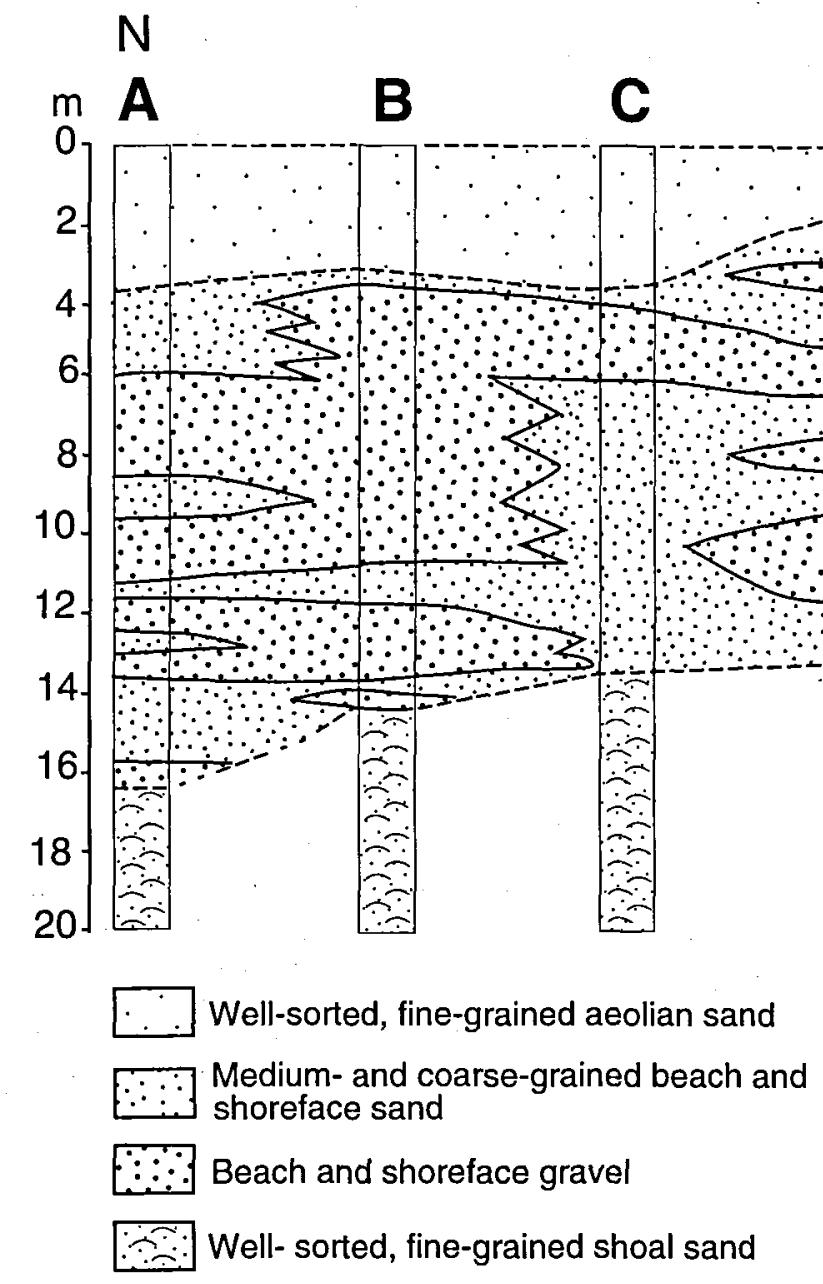

Fig. 4. Sedimentary buildup of the barrier core area.Borings were carried out by Ribe amtskommune et al. (1989). For location of borings see fig. 3 .

that the orientation of the shoreline is in equilibrium with the wave climate. At present there is a strong southward directed littoral transport of sediments leaving a net contribution of sandy sediment on the coast (Nielsen \& Nielsen 1990; Bartholdy \& Pejrup 1994).

Erosion of the Danish westcoast has taken place, and still goes on, in areas north of the Henne-Vejers area. The sediment transportation rate along the coast is in the order of $0.5-1.0 \times 10^{6} \mathrm{~m}^{6} /$ year (Bartholdy \& Pejrup 1994). Much of this sediment load is deposited at the coastal stretch between Blåvands Huk and Henne Strand, and according to Nielsen and Nielsen (1990) the progradation rate of the shoreline reaches $1 \mathrm{~m} /$ year. This dynamic situation of the shoreline is probably related to lee-effects created by the offshore Horns Rev.

\section{Georadar analysis}

Theory

The georadar method is an electro-magnetic measuring method, which records reflections from lithological boundaries and structures at shallow depths, in the Vejers area in the upper $20 \mathrm{~m}$ of strata, by using vertically transmitted radio-waves. The radio-waves are transmitted as pulses of short duration (a few nano seconds). The pulses are reflected from boundaries between layers of different electric conductivity and dielectric characteristics. A reflection is displayed as three dark bands separated by two thin white bands. Reflections are typically generated at the groundwater table or at the boundary between layers of different lithology (Ulriksen 1982; Ahrentzen 1987). The reflected radio-waves will return to the surface, where the time delay between transmission and receiving can be recorded, as well as the strength of the reflected signal. The part of the radio-waves which is not 

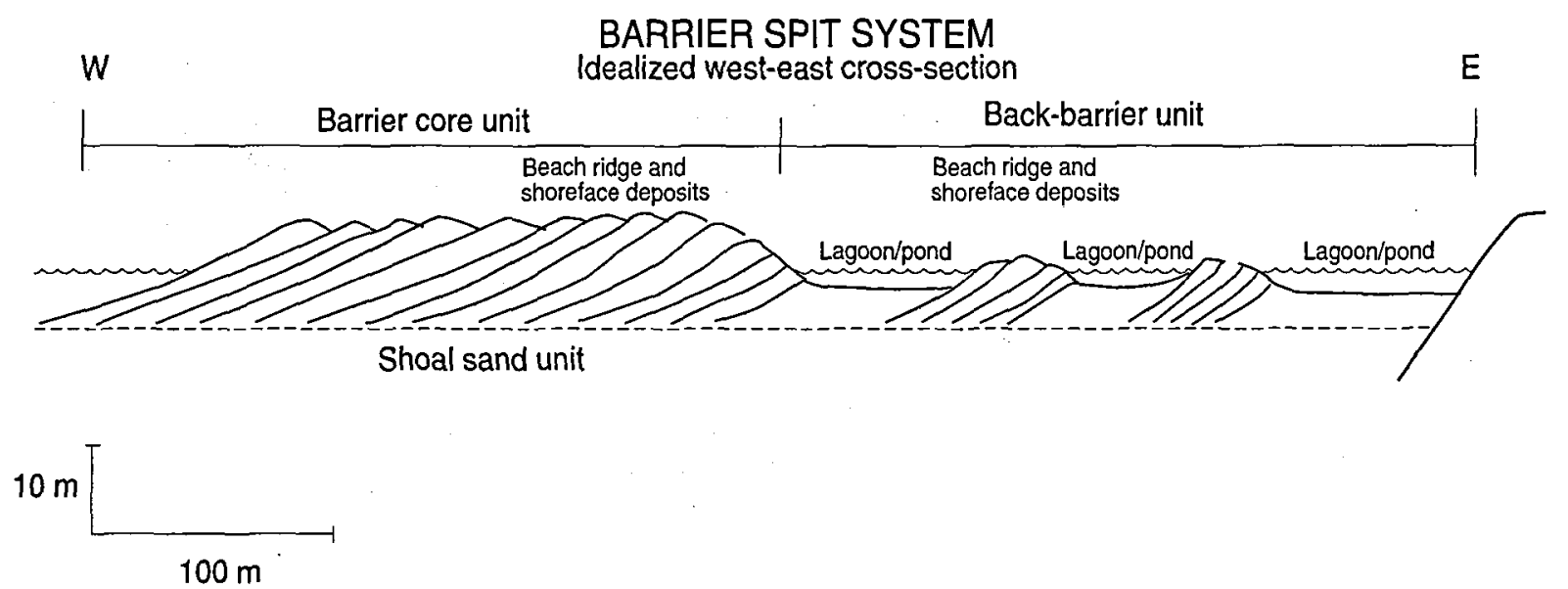

Fig. 5 Idealized cross-section of the barrier spit system at Vejers prior to large-scale aeolian sedimentation.

reflected at the first boundary will continue until a second boundary reflects a little more of the transmitted energy, etc. By slowly moving the transmitter and receiver during the measurement, a continuous picture of the upper strata is obtained (Ahrentzen 1987). In the recent years the georadar method has been used in a number of studies, e.g. Smith \& Jol 1992 and Jol et al.1994.

\section{Georadar mapping}

The georadar profiles from 1987, covering $72 \mathrm{~km}$, were distributed on fourteen profile-lines (I-XIV) with a prevailing west-east orientation, and one profile-line (XV) oriented south-north linking the west-east profiles (Fig. 3). The data from 1994 comprised of a number of profile-

lines in total $25.7 \mathrm{~km}$ south and east of lake Langsø. We based our interpretation of the georadar profiles on seven borings (Figs 3 and 4) made especially for the 1987 investigation (Ribe Amtskommune et al. 1989), the geological basic data map of the area (Danmarks Geologiske Undersøgelse 1983), sedimentological field studies in the area (Nielsen 1993) and C-14 datings. The georadar mapping in 1987 was carried out with an analog recording SIR (Subsurface Interface Radar) instrument from GSSI (Geophysical Survey Inc., USA) with a $300 \mathrm{MHz}$ antenna. In 1994 a digital instrument and $40 \mathrm{MHz}$ and $100 \mathrm{Mhz}$ antennae were used. Our interpretation has been made mainly on basis of the 1987 data.

Georadar mapping portrayed nicely the 3D-structure of the barrier spit system and associated deposits, and several georadar units were distinguished. These units were the shoal sand unit, the barrier core unit, the backbarrier unit and the aeolian unit (Fig. 5); these units were characterized by well developed reflector patterns, and generally had sharp boundaries. The distribution of the barrier core and back-barrier units defined the morphology of the barrier spit system (Figs 5 and 6). These units are therefore treated in some detail here with emphasis on the barrier core unit. The overlying aeolian deposits are described by Clemmensen et al. (in press). These deposits are composed of a Lower and Upper aeolian unit separated by a well-developed peat layer. Dune forms in the Upper unit include the present-day stabilized dune forms that reach heights of c. $20 \mathrm{~m}$.

\section{Field studies}

\section{Borings}

The stratigraphy of the area was examined through seven borings all carried out in 1987 (Ribe amtskommune et al.1989).

Five of the borings were made in the investigated barrier core area, and the last two were made in the back-barrier area further to the east (Fig. 3). The five borings from the barrier core area showed the following tripartite build-up (Fig. 4). The upper 1.5-3.5 m consisted of aeolian sand. Below approximately $10 \mathrm{~m}$ of gravel-rich barrier ridge and shoreface/beach deposits of the barrier core unit was found. The deposits were characterized by gravel layers and layers of coarse sand, but lenses of fine sand and silt, a few meters thick, were found too. The gravel fraction $(>4 \mathrm{~mm})$ of the deposits varied between 14 and 56\% (Ribe amtskommune et al. 1989). The barrier core unit was situated on a shoal sand unit, consisting of well-sorted fine to medium grained marine sand with shell fragments and a large content of silt and clay.

Almost the same facies pattern was seen in the water supply wells (Danmarks Geologiske Undersøgelse 1983) at Vejers, along the Grærup road, at Kærgaard 


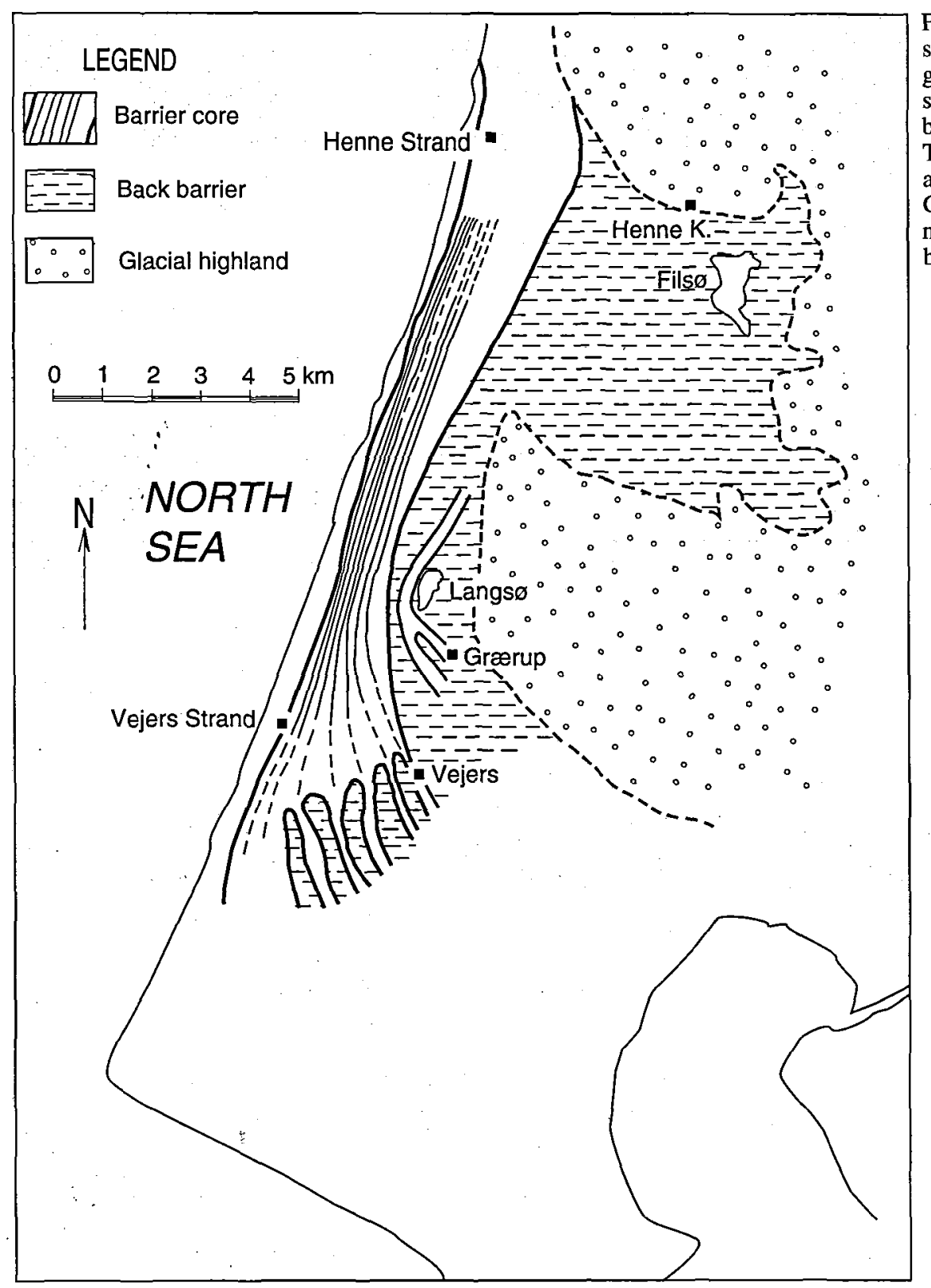

Fig. 6. Map of the barrier spit system at Vejers as revealed by georadar mapping. The main spit to the west shields the back-barrier area from the sea. The back-barrier area contains a minor spit structure near Grærup. The spit system is now to a large degree covered by aeolian sediments.

and at Henne Strand. Here 1-5 m of Holocene aeolian sand overlies Holocene marine sand and gravel, in some places this lower part was at least $12 \mathrm{~m}$ thick. Generally these wells were not so deep however, that the lower boundary of the Holocene sand and gravel was reached.

Two borings 10 and $13.5 \mathrm{~m}$ deep in the back-barrier area (Ribe amtskommune et al. 1989) showed that the sediments here are composed of well-sorted, fine- to medium-grained sand with a varying content of silt, plant fragments and peat (Fig. 3). In the northern part of thearea near Henne, clayey till has been found approximately $8 \mathrm{~m}$ below the surface; this till was not seen in the southern part of the area. The deposits have been interpreted as a sequence of "lagoonal" deposits, but we believe that there is much aeolian sand in the upper 4-10 $\mathrm{m}$ of the successions (cf. Clemmensen et al. in press).

\section{Outcrops}

Only a few natural gravel outcrops were present in the area, primarily in blow-outs or in the interdune corridors. At the Henne Mølleå stream the upper boundary of the gravel-rich beach ridge deposits was seen in the banks of the stream. Further to the west, at Henne 


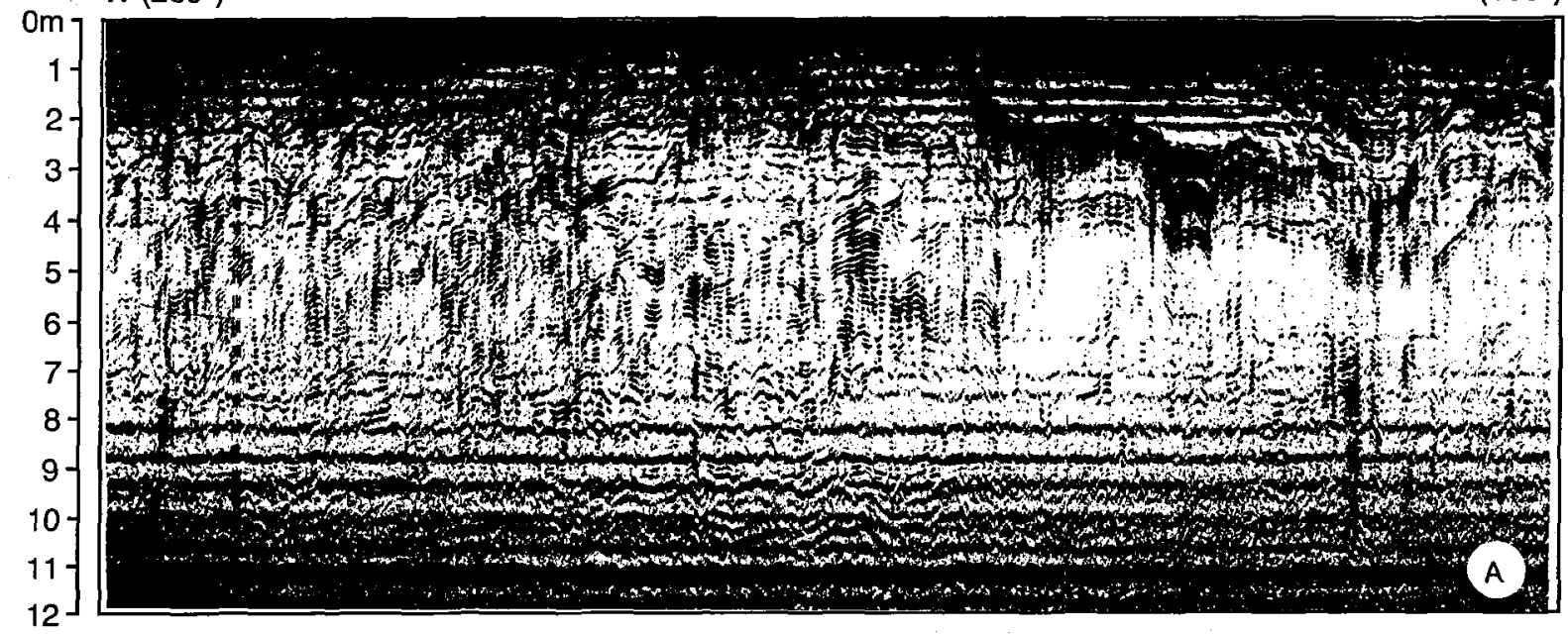

\begin{tabular}{|c|c|c|c|c|}
\hline$W\left(280^{\circ}\right)$ & 100 & 200 & 300 & $\begin{array}{r}400 \mathrm{~m} \\
\mathrm{E}\left(100^{\circ}\right)\end{array}$ \\
\hline
\end{tabular}

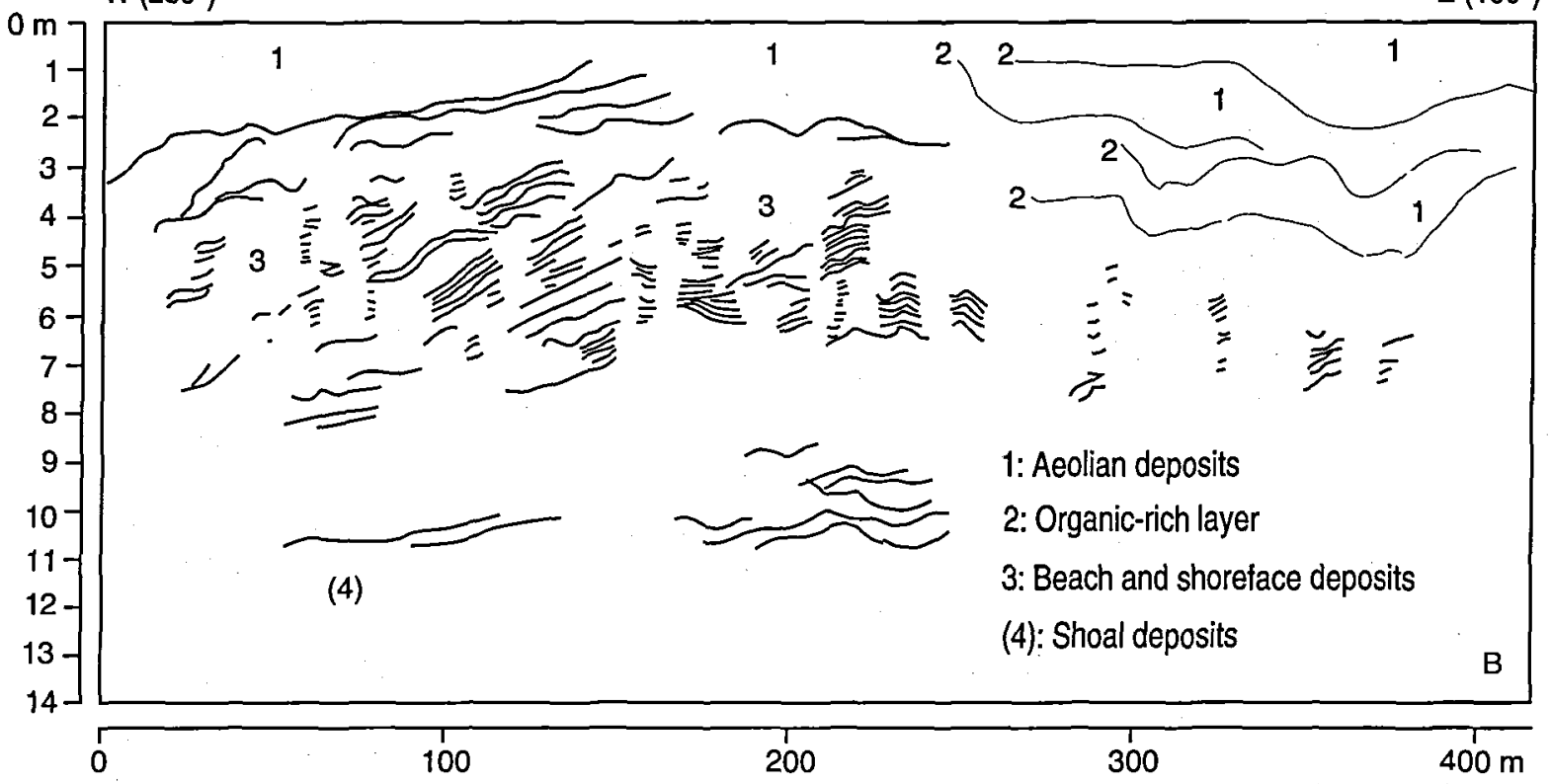

Fig. 7. Georadar profile (A) and line drawing (B) with interpreted genetic units (line VIII). Northern part of the main barrier spit system. Road level in this and following profiles $+6-+7 \mathrm{~m}$.

Strand, pebble pavements were recognized in blowouts approximately $0.3 \mathrm{~m}$ below an indistinct soil horizon within the aeolian deposits. The pebbles were oblate with a maximum size of $10 \mathrm{~cm}$ in diameter. Pebble pavements were also seen in several interdune corridors between Vejers and Grærup Strand.

\section{Datings}

Two main events date the most important phase of spit formation, during which rapid growth took place. The marine period of the Fils $\varnothing$ basin predates the peak phase of barrier spit formation, and the upper aeolian dune complex postdates this (Nielsen 1993).

Jonassen (1957) found that the Fils $\emptyset$ basin had a marine period from the end of the early Atlantic period to the end of the Atlantic period (c. 6500-4000 B.P.), and the marine period ended due to closing of the basin by barrier spit development and sanding up of an outlet at Henne Strand. A peat layer found at the boundary between the Lower and Upper aeolian units in an abandoned gravel pit near Langsø has been dated by "Kulstof-14 Dateringslaboratoriet" in Copenhagen to $1080 \pm 70{ }^{14} \mathrm{C}$ years B.P. (K-5876). This dating was 

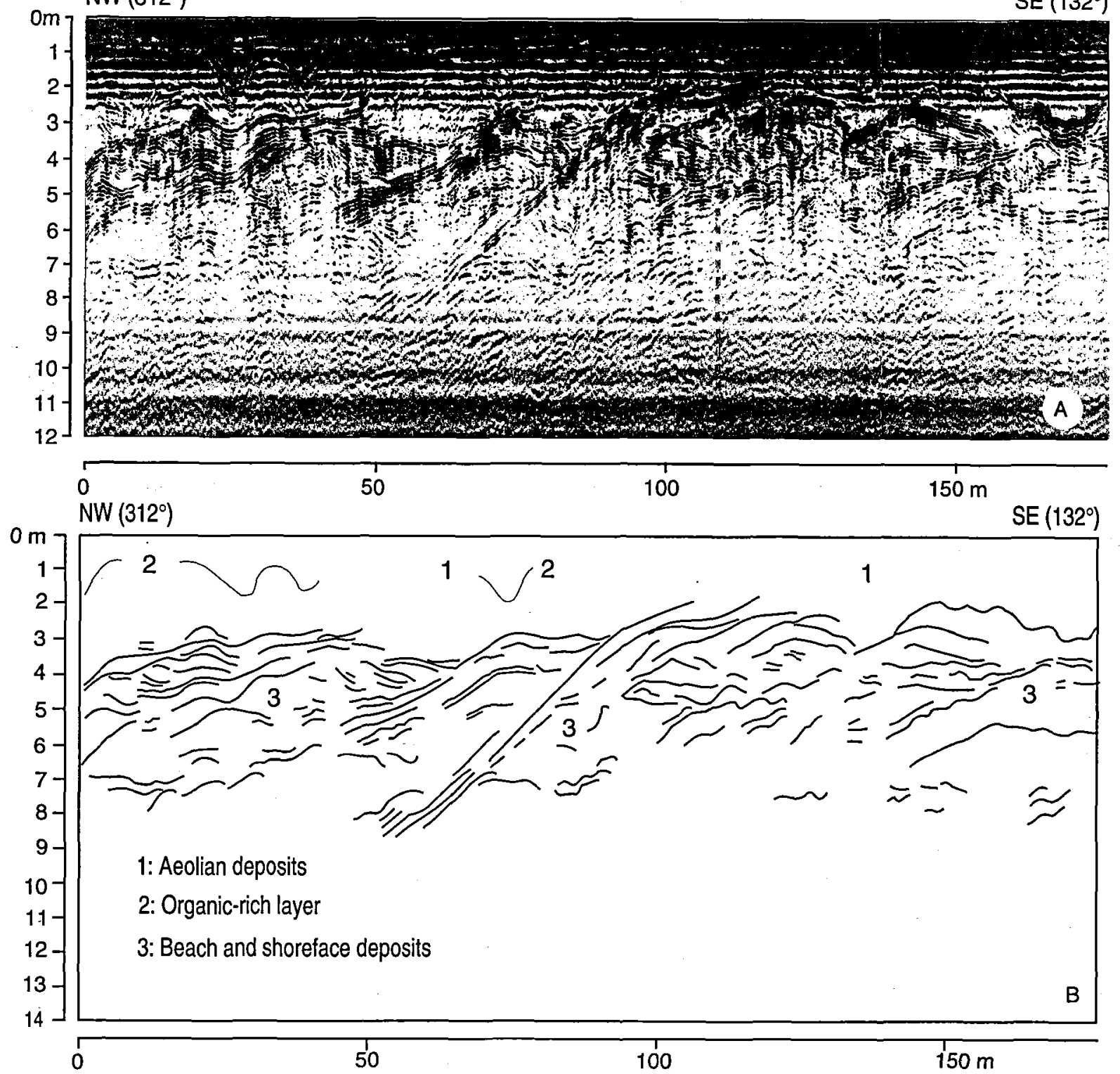

Fig. 8. Georadar profile (A) and line drawing (B) with interpreted genetic units (line II). Central part of the main barrier spit system.

calibrated to 890-1020 A.D. at one standard deviation (Stuiver \& Pearson 1993). A similar peat layer at Henne Mølleå was dated by the AMS ${ }^{14} \mathrm{C}$-dating facility in Arhus to $950 \pm 90{ }^{14} \mathrm{C}$ years B.P. or to $1010-1215$ A.D. at one standard deviation. This combined with finds of planks and a cup (A so-called Molling dated to 11001200 A.D.) in the gravel from the marine beach ridge deposits at Vejers, indicate that the gravel-rich barrier spit system is of middle to late Holocene age.

\section{Structure of the barrier spit system}

Barrier core unit

The barrier core unit was seen on all the georadar profiles (Fig. 3), though the georadar mapping revealed, that the architecture of the unit differed from north to south. The reflector pattern indicated, that these marine deposits comprised an approximately $10 \mathrm{~m}$ thick unit of alternating coarse sand and gravel with meterthick lenses of fine-grained sand and silt in between. The barrier core deposits were portrayed as well-defined westward dipping black reflectors. The lower boun- 


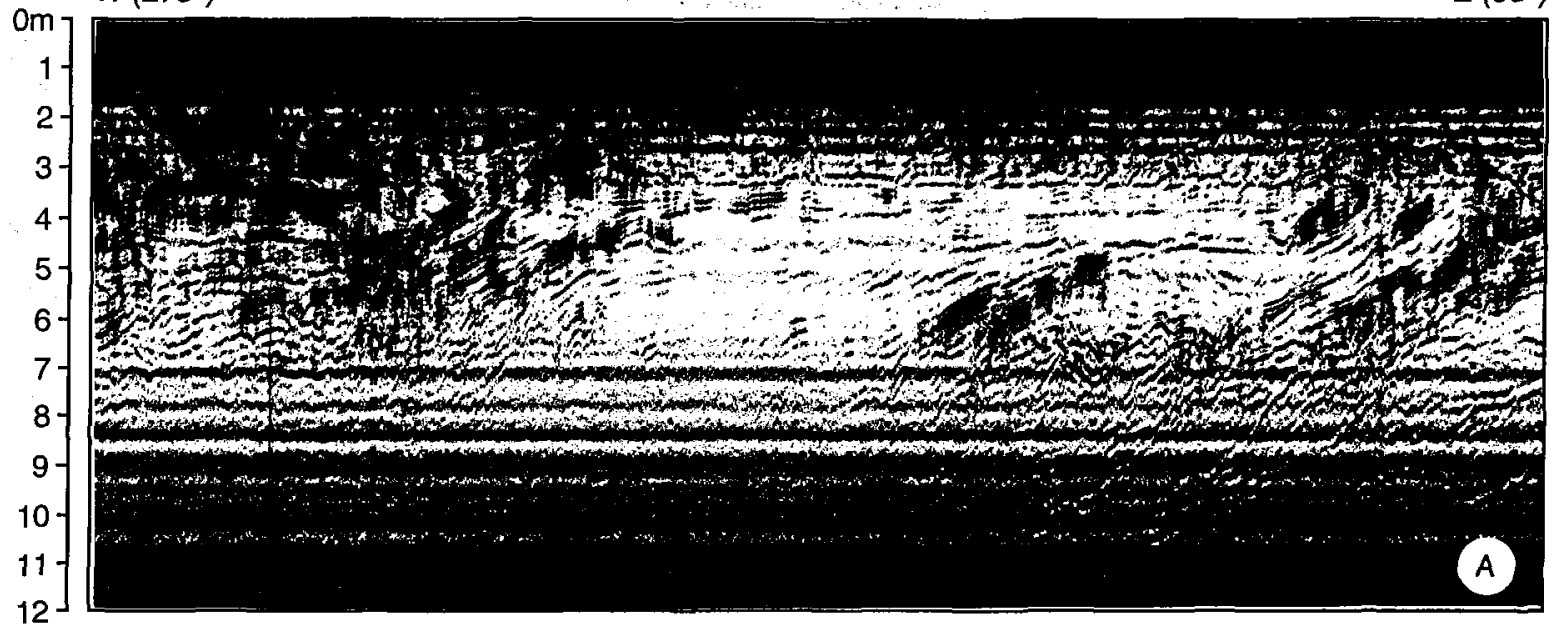

12

\begin{tabular}{|c|c|c|c|c|}
\hline $\begin{array}{l}0 \\
W\left(273^{\circ}\right)\end{array}$ & 100 & 200 & 300 & $400 \mathrm{~m}$ \\
\hline
\end{tabular}

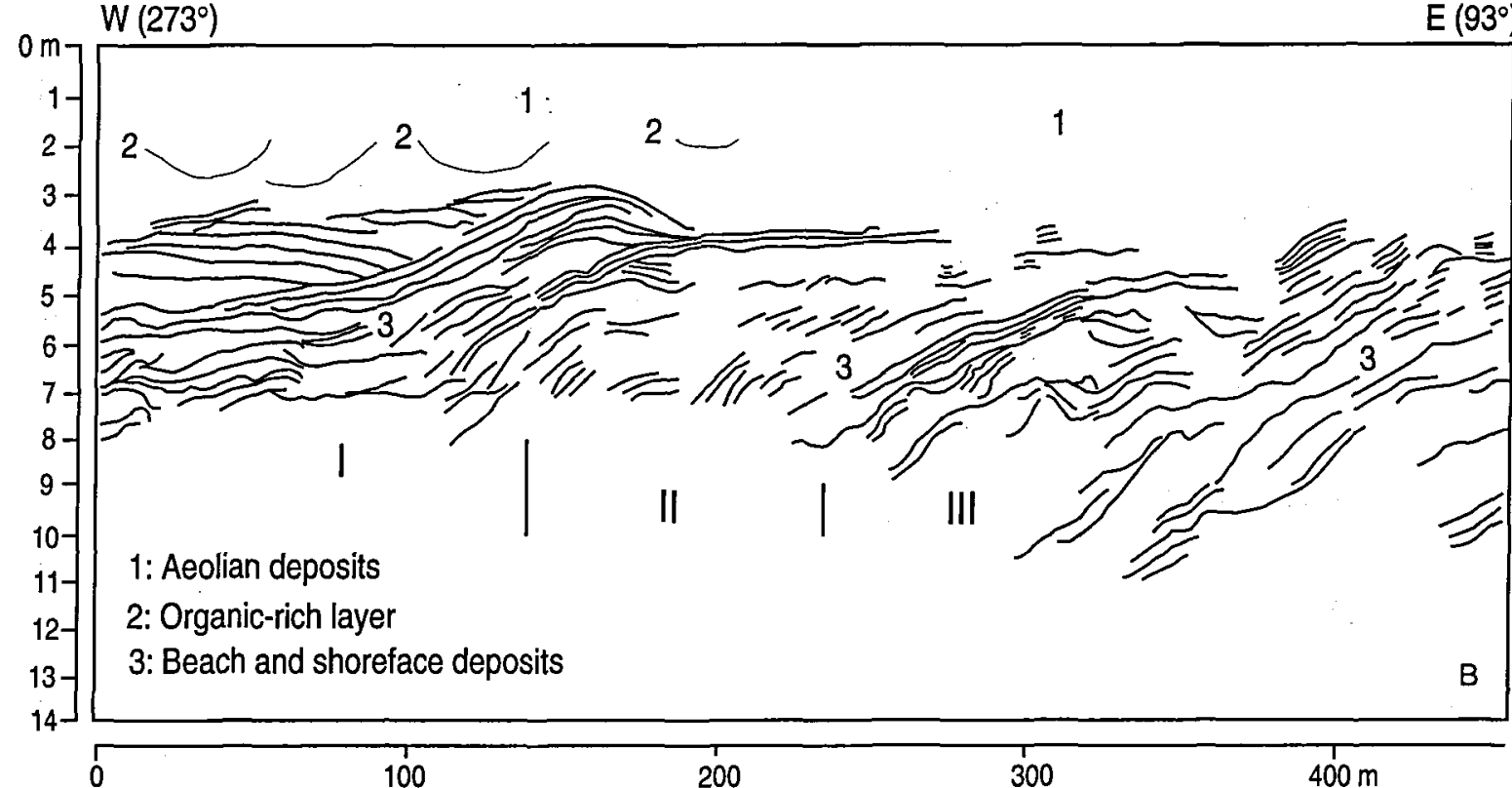

Fig. 9. Georadar profile (A) and line drawing (B) with interpreted genetic units (E-W part of line VII). Southern part of the main barrier spit system. The beach deposits display a lateral zonation (I, II, III).

dary of the barrier core unit was seen in the borings (Fig. 4) as a marked increase in grain size from silt and sand (shoal sand unit) to gravel and sand. On the georadar profiles this boundary was poorly defined. The main barrier core unit was bounded seawards by a marine unit made up of present day beach and shoreface sands. The barrier core unit was sharply overlain by an aeolian unit of coastal dune and aeolian sand sheet deposits.The upper boundary of the barrier core unit was characterized in the borings by a shift from marine gravel-rich deposits to well-sorted, fine- to medium-grained aeolian deposits (Fig. 4). On the georadar profiles this boundary was typically portrayed by a change from well-defined black reflectors to weak, blurred reflectors dipping towards the east, or to weak hummocky reflectors.

In the northern part of the area, north of profile No. $\mathrm{V}$ the barrier core unit appeared as one massive ridge of coarse sand, gravel and pebbles approximately 1.2 $\mathrm{km}$ wide, with no clear separation between shoreface and beach deposits (Fig. 7). The reflectors of the unit were black, a few $\mathrm{cm}$ long (20-30 $\mathrm{m}$ in deposit) with a westerly dip ( $4-5^{\circ}$ apparent dip). There was no clear internal boundary in this part of the unit. The lower 


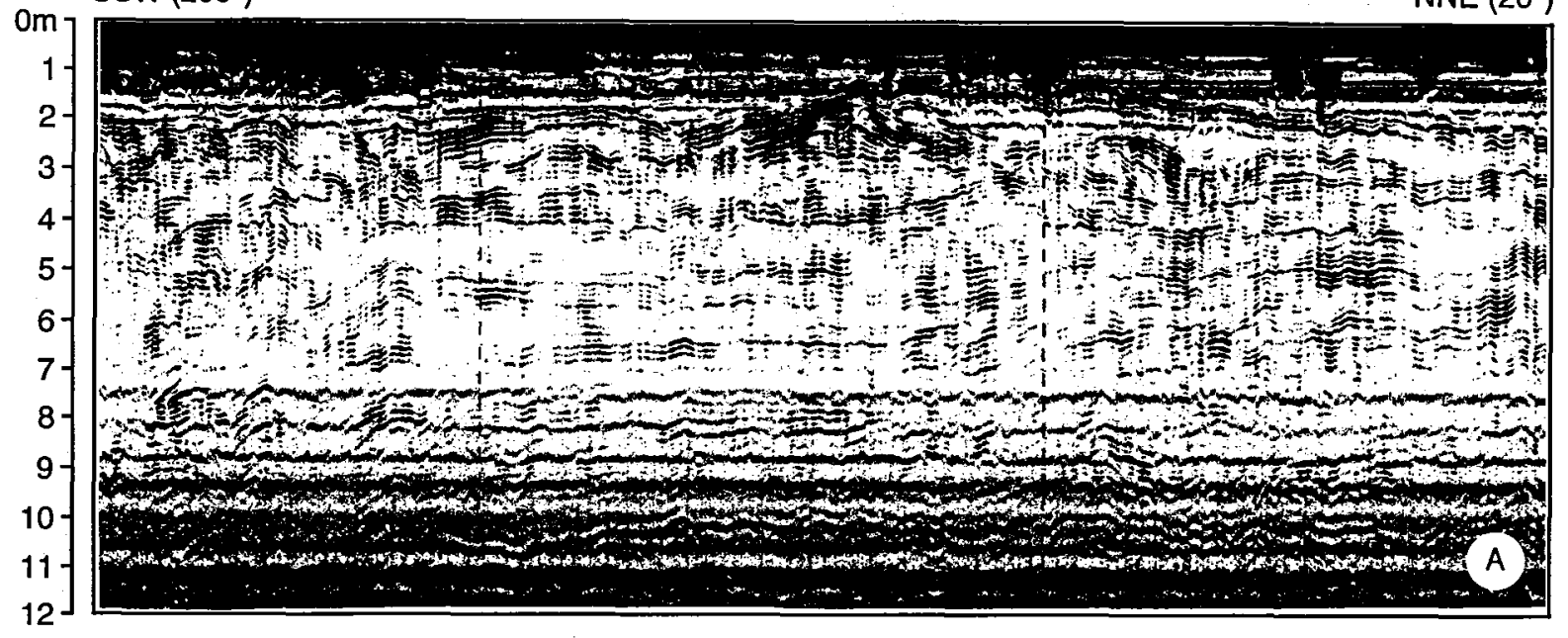

\begin{tabular}{llrr}
\hline $\operatorname{SSW}\left(200^{\circ}\right)$ & 50 & 100 & $150 \mathrm{~m}$ \\
& & $\operatorname{NNE}\left(20^{\circ}\right)$
\end{tabular}

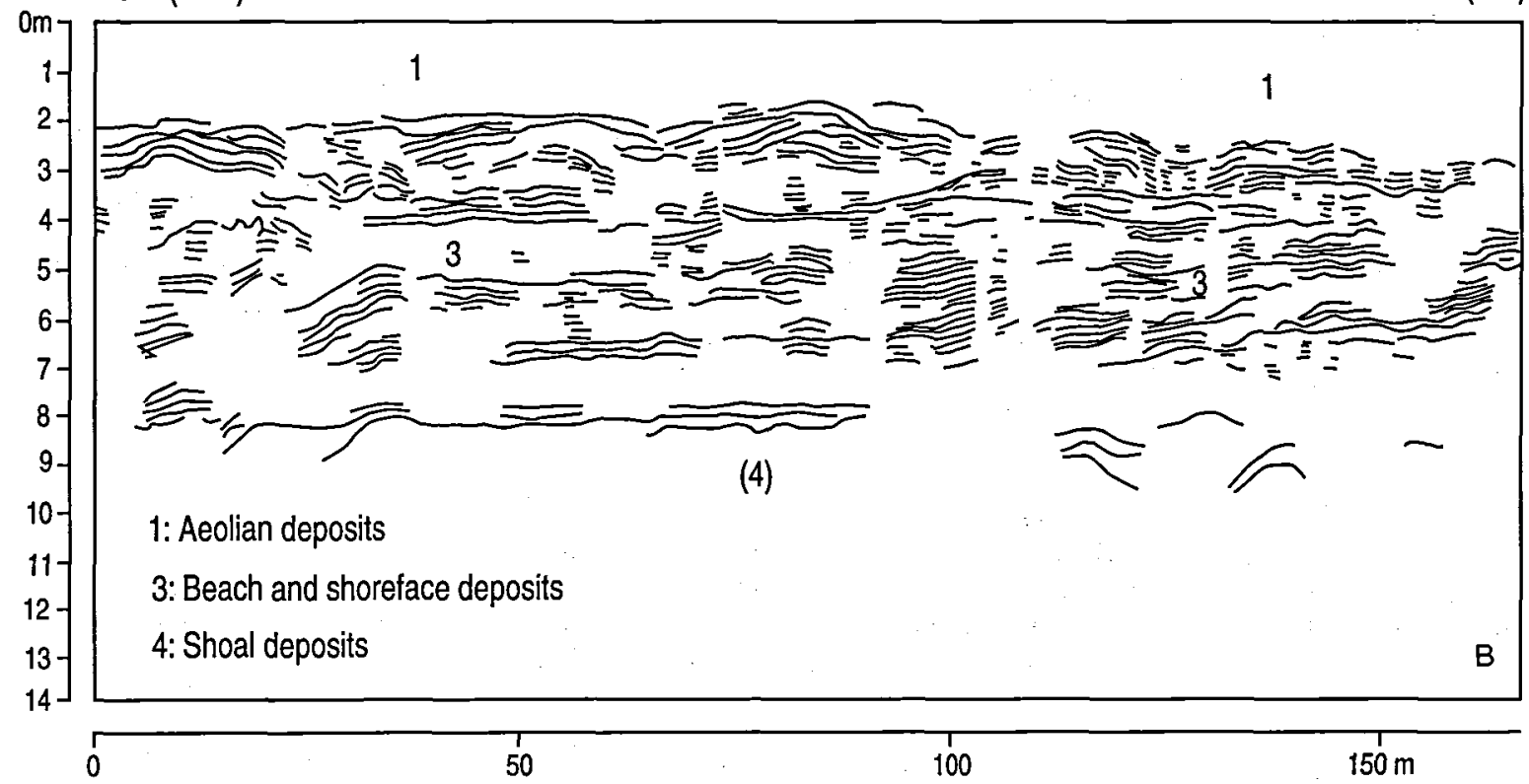

Fig. 10. Georadar profile (A) and line drawing (B) with interpreted genetic units (line XV). Central part of the main barrier spit system.

boundary seen in the borings (Fig. 4) was placed at the base of the heavy, inclined reflectors (Fig. 7). The upper boundary was only weakly developed on profile No. V, but better defined on profile No. VIII (Fig. 7).

The barrier core unit continued into the central part of the area (profile No. I, II, III, IV, V, XIII and XIV) (Fig. 3). Here the reflector pattern of the core unit was approximately $1-1.5 \mathrm{~km}$ wide being most narrow in the southern part of this area. Eastward of the main unit a minor second barrier core unit was seen (Fig. 6). It was separated from the main structure by a backbarrier unit (discussed later). The second barrier core unit was smaller and had a less pronounced appearance due to a lower content of coarse material than the more westerly situated main barrier core unit. The reflector pattern of the minor structure was very weak on profile No. V (proximal part), but further south on profile No. III the structure was approximately $200 \mathrm{~m}$ wide and clearly seen. South of lake Langsø the structure split into two southeast curved ridges, each one $200 \mathrm{~m}$ wide (Fig. 6) (profile No. I, II, XIII and XIV). Both the main barrier core unit and the second minor one showed internal reflectors dipping $2-3^{\circ}$ (apparent dip) towards west. The main barrier core unit continued 
towards south, while the two ridges of the minor one died out approximately $1 \mathrm{~km}$ south of Grærup.

The lower boundary of the main barrier core unit known from boring C (Fig. 4) was in the central part of the area also placed at the base of the heavy, inclined reflectors (Fig. 8). The upper boundary of the barrier core unit showed an undulating amplitude of $0.5-2 \mathrm{~m}$, and was clearly seen on the georadar profiles as a marked shift in reflector pattern especially on profile I and II (Figs 3 and 8), while the change in reflector pattern at the boundary was less obvious on profile IV and V (Fig. 3). In the central area indistinct, blurred reflectors interpreted as aeolian deposits were lying above the barrier core unit, and in the most eastern part of the barrier core unit on profile No. I a welldefined reflector of a peat- or organic-rich layer was seen within the aeolian succession. The organic-rich layer was repeated on top of the second barrier core unit in profile No. I. The upper boundary of the barrier core deposits was situated $2-3 \mathrm{~m}$ below the surface.

In the southern part of the investigated area (profile No. VI, VII, X, XI and XII), the reflector pattern showed a disintegration of the main barrier core unit into six eastward concave ridges separated by finegrained deposits (Fig. 6) (discussed later). The most western ridge showed no westward termination. The ridges were $200-375 \mathrm{~m}$ wide, the most narrow one situated northeast and the most wide one to the southwest. The height of the ridges relative to the bottom of the surrounding depressions was $2-7 \mathrm{~m}$, highest in the southwestern part and lowest in the northeastern part. The terminations of the ridges were situated outside the investigated area. A detailed investigation of this particular area is planned. The lower boundary known from the borings D and E (Fig. 4) was not clearly seen on the georadar profiles, but well-defined, inclined reflectors disappeared approximately $6 \mathrm{~m}$ below the top of the unit (Fig. 9). The upper boundary of the barrier core unit was here marked by an abrupt change in reflector pattern. The internal reflectors in the aeolian unit were mostly indistinct and blurred (Fig. 9), while the internal reflectors in the barrier core unit were clear, broad andblack. These later reflectors were several $\mathrm{cm}$ long on the georadar profiles (or $20-30 \mathrm{~m}$ in deposit) and dipped $1-4^{\circ}$ (apparent dip) towards the west.

In a longitudinal section (Fig. 10) (profile No. XV, Fig. 3) the reflectors of the barrier core unit appear as long, clear and sub-horizontal and may be seen down to approximately $10 \mathrm{~m}$ below the surface (Fig. 10). The upper boundary of the barrier core unit was undulating and relatively well-defined, while the lower boundary was rather poorly defined. It was remarkable that no south-ward dipping reflectors were seen in the barrier core unit (discussed later).

\section{Back-barrier unit}

The back-barrier unit was situated in the most eastern and southern parts of the mapped area (Fig. 6). The back-barrier area was shielded from the coast by the main spit structure, and its genesis was related to the development of this depositional element (Fig. 6).

The back-barrier unit had a rather complex sedimentary architecture. It contained minor spit structures and well-developed examples occurred around Langsø (Fig. 6). The back-barrier unit was generally speaking composed of basal lagoonal or pond deposits (fine-grained silty sand) overlain by aeolian deposits, that contained several organic-rich horizons, but there was much local variety (Clemmensen et al. in press). The back-barrier unit was underlain by marine deposits. These deposits were here collectively termed the shoal sand unit, but on the new georadar profiles from 1994 it was obvious that also this unit had a complex sedimentary architecture. Depositional sub-units recognized included shoreface and beach deposits (presumably an older system) and tidal dune sand deposits.

The georadar profiles and data from borings revealed that the base of the back-barrier unit typically was developed as a peat layer (cf. Clemmensen et al, in press). Then followed fine-grained silty sediments of lagoonal or pond origin. A second well-developed peat layer occurred on top of these deposits and was followed by an up to $8 \mathrm{~m}$ thick succession of aeolian deposits. The aeolian deposits contained three internal peat horizons.

\section{Sea level changes}

In order to understand the coastal behavior and sea level changes in the Henne-Vejers area, Denmark, it is necessary to consider the isostatic rebound and subsidence, that has influenced the Danish area the last 8500 sidereal years. Mertz (1924) published a map showing isobases for the Littorina transgression maximum (7000-5000 B.P.) in Denmark. From this map it appears, that the northern part of Denmark has been uplifted, while the southern part, including the Henne-Vejers area, has been subject to subsidence since the Littorina transgression maximum. Petersen (1991) demonstrated, that the isostatic rebound in the northern part of Denmark has been decreasing during the Holocene, and that it almost came to an end 2000 B.P. Studies of Iron Age settlements in southern Denmark (Petersen 1985) also indicated that there has been no measurable subsidence in this area during the last 2000 years or so.

This is in agreement with the sea level curve established in the Eider Estuary in Germany (Fig. 11). Here a linear trend 2000-5000 B.P. shows a subsidence of $-0.66 \pm 0.13 \mathrm{~m} / 1000$ sidereal years (Shennan 1992). The Henne-Vejers area is situated halfway between 


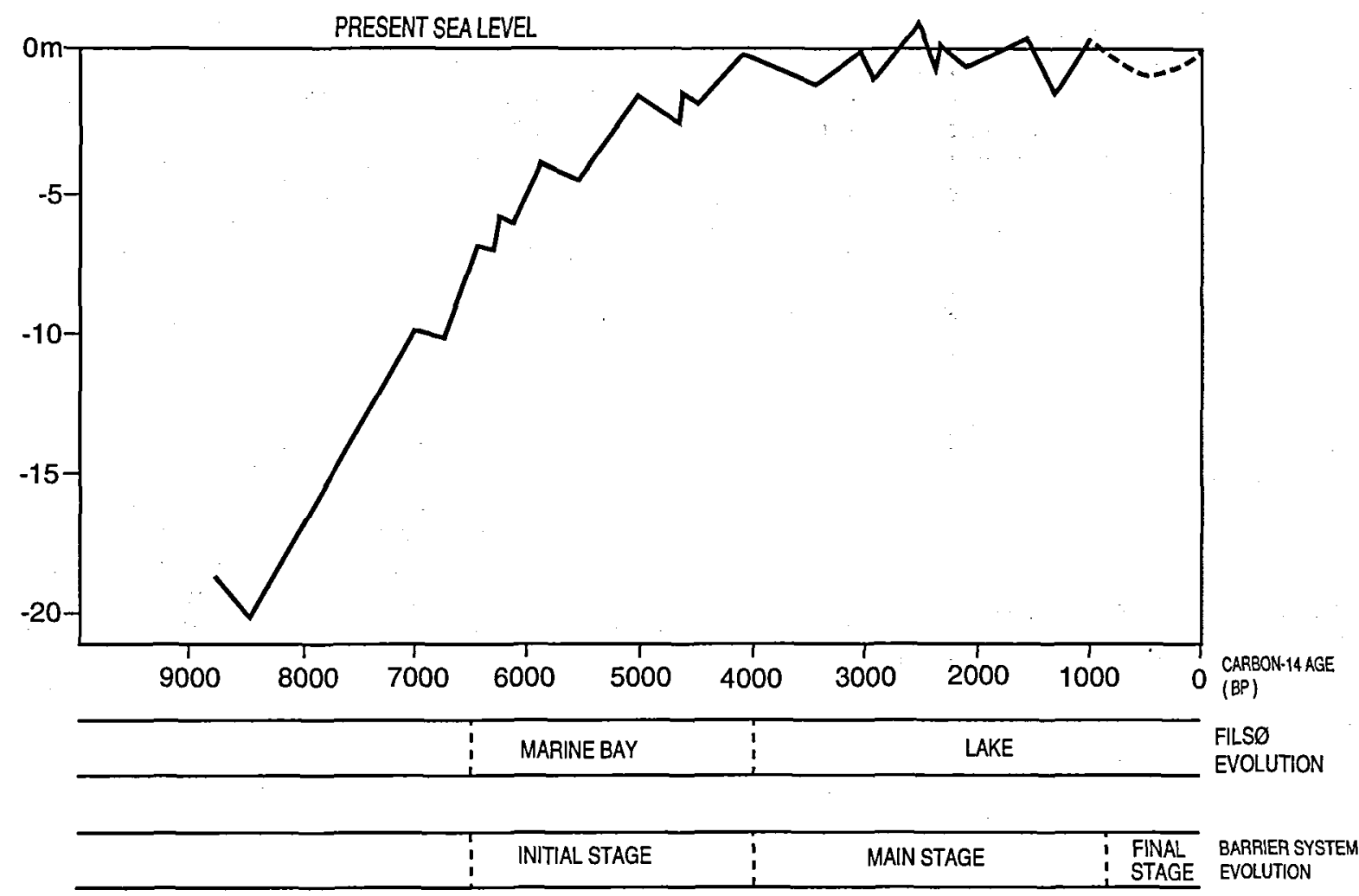

Fig. 11. Barrier spit dynamics in relation to Holocene sea level changes in the North Sea. The sea level curve is from Shennan (1992), while data on the Filsø evolution are from Krog (1979); Odgaard (1985).

Mertz' (1924) zero line, and the Eider estuary. By assuming a linear trend, interpolation of the subsidence rate yields about $-0.33 \pm 0.13 \mathrm{~m} / 1000$ sidereal years in the Henne-Vejers area, where, consequently, a total subsidence since the Littorina transgression of c. 1.65 $\mathrm{m}$ was expected.

An eustatic sea level curve covering the Kattegat region in the southern Scandinavia was presented by Mörner (1976). Later Mörner (1980) established the fact, that his eustatic sea level curve covered the last 9000 years of the entire northwest European region. Shennan (1992) used Mörners $(1971,1976)$ data to construct the regional eustatic sea level curve for the North Sea area (Fig. 11).

We believe, that the regional eustatic curve of the North Sea presented by Shennan (1992) is a good indicator of the relative sea level changes in the HenneVejers area especially during the last few thousand years (Fig. 11).

Most recently Tanner (1993) constructed a Holocene sea level curve from studies of beach ridge deposits in northern Jutland. The curve of Tanner (1993) differed somewhat from the sea level curve of Shennan (1992), and Tanner (1993) suggested much larger sea-level fluctuations in middle and late Holocene times. The curve of Shennan (1992) is here used to characterize the development of the North Sea during the last 9000 years, and the curve is divided into four sections, which seems to correspond to different stages of the Vejers barrier spit system formation.

Between 8500 B.P. and approximately 6500 B.P. the eustatic curve represents a relatively fast sea level rise (c. $6.5 \mathrm{~m}$ per 1000 years) from $-20.2 \mathrm{~m}$ to $-7.5 \mathrm{~m}$ below the present sea level (Fig. 11). The eustatic sea level curve only displays minor fluctuations during this period of early transgression. During this period shoals seem to have formed along the coast. From approximately 6500 B.P. to 4000 B.P. the sea level rise declined, and sea level fluctuations became larger (Fig. 11). This was the period of initial spit formation. From 4000 B.P. to 1200 A.D. sea level was high and fluctuated somewhat (Fig. 11). In the beginning of this period the sea level reached its maximum at $+0.6 \mathrm{~m}$. This is the period of rapid southward growth as well as seaward progradation of gravel-rich deposits. In the last 800 years the sea level remained high, but showed one main sea-level drop related to the "Little Ice Age" (cf. Tanner 1993, Fig. 11). This was the period of continued spit growth primarily by sandy deposits and also the period of large-scale aeolian dune formation.

It has been a matter of speculation why the elevation of the gravel-rich beach ridges in the Vejers area 
reached a maximum level of $+4-+4.5 \mathrm{~m}$. This level is above the present day storm surge level (approximately in $2 \mathrm{~m}$ ) corresponding to the maximum level of the present day sandy beach ridges. This represents a problem especially because the whole area is supposed to have subsided about $2 \mathrm{~m}$ since the Littorina transgression. Jessen (1925) was the first who noticed this, and he concluded that the height of the beach ridges must have come from a minor uplift of the area. Alternatively the height of the beach ridges could indicate a sea level fall of at least $2 \mathrm{~m}$ since their formation. But this difference in altitude may also be explained as a result of a different wave climate and/or different sediment supply conditions (cf. Orford, Carter \& Jennings 1991).

\section{Development of the barrier spit system}

Galloway (1986) defined the barrier core as the massive, strike-elongate sand skeleton of the barrier. The core is according to Galloway (1986) composed of beach, dune and upper shoreface sands. We here modify this definition, and consider the barrier core unit of the Vejers system to be composed of strike-elongate gravels of beach and upper shoreface environments. The coastal dune sand and associated aeolian sediments are sufficiently specific in this system to be dealt with as an independent unit (Clemmensen et al. in press).

Davies (1972) characterized barriers as either driftaligned or swash-aligned. The drift-aligned barriers have one point source from which the barriers are stretching downdrift, eventually to close a bay or fill out an inlet. Present day drift-alignment is marked by stronggradients in wave processes, especially in terms of wave approach angle, longshore currents and wave height (Carter, Jennings \& Orford 1990). The driftaligned barriers are weak and very sensitive to adequate sediment transport. They can only survive if long-term sediment supply is maintained. Deficient sediment supply will make them start cannibalizing the proximal parts (Oxford et al. 1991).

Swash-aligned barriers form where the shoreline curve parallels the incoming wave crests, creating conditions where the wave-thrust is orthogonal to the beach (Orford et al. 1991). In this situation, there will be no potential for net longshore sediment transport. When sediment supply is abundant, swash-aligned barriers tend to prograde seaward (Orford et al. 1991).

Thus, barrier beaches may embrace both drift- and swash-aligned forms, especially during phases of barrier extension or breakdown (Orford et al. 1991).

The georadar mapping presented in this paper demonstrates, that the gravel-rich barrier spit system structurally has a varying appearance from the proximal to the distal part.

We see several indicators suggesting that the system represents a drift-aligned barrier spit. (1) The barrier spit stretches from north to south, (2) it is closing a bay (the Fils $\varnothing$ basin), and (3) there is one main source of material, situated north of the barrier spit system.

The swash-alignment model, on the other hand, is supported by (1) westward prograding beach ridges, (2) the missing southward dipping strata, and (3) the NNE-SSW trend of the gravel-rich beach ridges, an orientation that is parallel to the present shoreline and to the crests of the constructing waves. Especially the lack of large-scale southward dipping strata is noteworthy as such structures should form in connection with southward progradation of the spit platform (cf. Nielsen et al. 1988).

What we see is apparently a combined drift- and swash-aligned barrier spit system. The spit developed under the influence of a strong southward directed sediment transport. Coarse-grained sediments were transported from the headland at Blåbjerg in the direction of the littoral drift, but the spit was primarily a swashaligned form with a shape controlled by the wave crests of western and northwestern waves that were refracted at the headland at Blåbjerg. This system finally developed as a linked barrier or as a Zeta form bay (cf. Davis, 1972). The location of initial shoals may also have influenced spit growth and orientation. The spit progradation towards the west indicates a strong positive sediment budget probably related to lee-effects created by the offshore Horns Rev.

The georadar profiles from the main barrier core unit show a series of low-angle westward dipping subunits with regular spacings around $20-25 \mathrm{~m}$ (Fig. 8). These sub-units reflect a gradual seaward progradation of the spit controlled by alternating periods of constructive and destructive waves. This does not necessarily involve eustatic changes; climatic changes of varying durability, e.g. seasonal changes or short-term variations (10-100 years) in storm frequency, may be enough to explain this pattern. Similar progradational gravelrich sequences are rare in the stratigraphic record, but well-exposed examples are described by Massari \& Parea (1988).

According to Orford et al. (1991) is it not possible to use the altitude of old beach ridges in determination of relative sea level changes. The height of the beach ridges, internal distance and volume is governed by frequency and intensity of storms combined with sediment supply. It seems possible (Orford et al. 1991), that former morphology in the area may control the formation of the beach ridges by wave domain control. Thus, the height of the ancient beach ridges in the Vejers area could be due to changes in sediment supply and/or changes in wave domain and not caused by an uplift or sea level fall.

There are only a few datings in the area, so we have been forced to use datings from the nearby Fils $\emptyset$ area. Those datings have shown, that the formation of the gravel-rich barrier spit system took place between approximately 6500 B.P. and approximately 1200 A.D. We have only few recordings of the spit development 
rate, but we do know that the Fils $\emptyset$ basin was separated from the North Sea around 4000 B.P., and accumulation of gravel-rich beach ridges ended around 1200 A.D.

\section{Conclusions}

The rising sea level following the last ice age exposed the irregular western coast of Jutland to erosion. A simplification of the coastline took place, and the eroded material was deposited in lee-areas along the coast.

Georadar mapping of the Vejers area exposed a coarse-grained barrier spit system consisting of a main barrier spit separated from a minor one by fine-grained back-barrier deposits. The smaller one, approximately $200 \mathrm{~m}$ wide, was found in front of the Grærup Inland Cliff, and disappeared just south of Grærup. The main barrier spit had an average width of $1000 \mathrm{~m}$. It spread from Varde bakkes $\emptyset$ in the north to Vejers in the south, where it split into six ridges of varying size.

The main barrier spit shows a southward elongated form, but no internal signs of southward growth have been preserved. Internal westward dipping georadar reflectors nicely display a westward prograding pattern, which lead to the conclusion, that the barrier spit system formed as a combined drift- and swash-aligned feature that finally developed as a linked barrier between a northern headland at Blåbjerg and a southern "headland" at Blåvands Huk.

Apparently barrier spit system evolution took place in three stages (Fig. 11). In the initial stage between c. 6000 and c. 4000 B.P. an early spit system grew southward during a period of rapidly, but decreasing sea level rise. In the main stage (4000 B.P.-1200 A.D.) spit growth continued towards the south, closed off the Filsø basin and at the same time rapid westward progradation of the spit system took place during a period of a generally high, but fluctuating sea level. Small aeolian dunes were developed on top of the barrier core deposits in this period. In the final stage of evolution (1200 A.D. to present) the coarse-grained sediment source was cut off but much sand was still added to the spit which continued to build southward and was eventually linked with the Blàvands Huk. The modern spit Skallingen formed during the last 300400 Years (Bartholdy \& Pejrup, 1994). Part of the sand deposited at the beach areas was in this stage redeposited by wind forming widespread coastal dunes and aeolian sand sheets.

\section{Dansk sammendrag}

Et Holocænt barrieresystem i Henne-Vejers området på den jyske vestkyst er blevet kortlagt ved brug af en georadar. Barrieresystemet består af en overordnet odde, der strækker sig fra Varde bakkeø i nord til Vejers i syd og en øst for liggende lavning (bagbarriere) med lagune aflejringer, æoliske sedimenter og søaflejringer. En lokal odde ses nær Langsø.

De indsamlede georadardata omfatter $72 \mathrm{~km}$ profiler fordelt på 14 linier orienteret vest-øst og 1 nordsyd orienteret linie. Georadarprofilerne blev opmălt $i$ 1987 samt i 1991 og 1994. Tolkningen af georadarprofilerne er baseret på analyser af boreprøver, naturskabte profiler, forladte grusgrave samt enkelte dateringer af tørveprøver.

Barriereodden udviser en tredelt opbygning. Den nederste enhed består af velsorteret, fint- til mellemkornet, marint sand (sandflade). Herover følger skiftende lag af groft sand, ral og sten (barrierekerne). Disse lag har en vestlig hældning på $2-5^{\circ}$ og repræsenterer prograderende strand- og kystplanaflejringer. Over disse lag findes æoliske klit- og sandsletteaflejringer. Oddeaflejringerne går mod øst over i en enhed opbygget af fint- til mellem-kornet sand med varierende indhold af silt og flere veludviklede horisonter med højt organisk indhold (bagbarriere). Også disse sedimenter dækkes af æolișke sandaflejringer.

Henne-Vejers området har sandsynligvis været udsat for en mindre isostatisk indsynkning siden den maksimale Littorinatransgression, og vi anser det for sandsynligt, at indsynkningen sluttede for ca. 2000 år siden. En eustatisk havniveaukurve er derfor en god indikator for havniveauandringerne i Henne-Vejers området specielt gennem de sidste 2000 år. Kurven viser en hurtig stigning $i$ havniveau mellem 8500 B.P. og ca. 6500 B.P., et stadigt stigende havniveau mellem 6500 B.P. og 4000 B.P., et generelt højt havniveau dog med flere betydelige fluktuationer mellem 4000 B.P. og 1200 A.D., og et fortsat højt havniveau efter 1200 A.D. Barriereoddens dynamik afspejles i de bagved liggende lagune- og søsystemers udvikling (Filsø og Langs $\emptyset$ ) og hele systemets sedimentære udvikling kan opdeles i tre hovedstadier.

Et indledende stadium i perioden $6500-4000$ B.P. (transgression), hvor den første udbygning mod syd af barriereodden sker. Et hovedstadium i perioden 4000 B.P.-1200 A.D. (tidlig højstand), hvor odden prograderer mod vest og væksten mod syd samtidig fortsætter. I begyndelsen af denne fase afsn $\varnothing$ res den bagved liggende lagune og omdannes til et søsystem. Et sent stadium efter 1200 A.D. (højstand), hvor tilførslen af grovklastisk materiale ophører og hvor storskala klitdannelse finder sted.

Barriereodden blev udviklet mellem det eksisterende moræneparti ved Blåbjerg og Blåvands Huk. Oddens udvikling skete under indflydelse af en stor sydgående sedimenttransport, men oddens overordnede orientering blev tilsyneladende primært styret af bølgeprocesser. 


\section{Acknowledgements}

The authors wish to thank Jesper Bartholdy for fruitful discussions, Erik Sten for support during the fieldwork, and Rene Madsen for making the illustrations. We would also like to thank the AMS ${ }^{14} \mathrm{C}$-dating facility in Århus and Kulstof-14 Dateringslaboratoriet in Copenhagen for dating of peat samples. Constructive comments by the reviewers are gratefully acknowledged.

\section{References}

Ahrentzen, P. 1987. Georadar-metoden. In: Geofysik og råstofkortlægning, Råstofkontorets korttlægningsserie 5, Skov- og Naturstyrelsen, 123-134.

Bartholdy, J. \& Pejrup, M. 1994: Holocene evolution of the danish Wadden Sea. Senckenbergina maritima 24, 187 209.

Carter, R. W. G., Jennings, S. C., \& Oxford, J. D. 1990. Headland erosion by waves. Journal of Coastal Research $6,517-529$.

Clemmensen, L., Andreasen, F., Nielsen, S.T. \& Sten, E. (in press): The late Holocene coastal dunefield at Vejers, Denmark: characteristics, sand budget and depositional dynamics. Geomorphology.

Davies, J. 1972: Geographical Variation in Coastline Development. Oliver and Boyd, Edinburgh, 204 pp. Danmarks Geologiske Undersøgelse 1983. Geologisk Basisdatakort, 1113 IV Varde.

Galloway, W.E. 1986: Resevoir Facies Architecture and Microtidal Barrier Systems. The American Association of Petroleum Geologists Bulletin 70, 787-808.

Jessen, A. 1925: Beskrivelse til Geologisk kort over Danmark. Kortbladet Blåvandshuk. Danmarks Geologiske Unders $\emptyset$ gelse, I. rk. nr. 16, 1-76.

Jol, H. M., Meyers, R. A., Lawton, D. C. \& Smith, D. G. 1994: A detailed ground penetrating radar investigation of a coastal barrier spit, Long Beach, Washington, U.S.A. In Bell, R. S. \& Lepper, C. M. (Eds) Proceedings of the symposium on the application of geophysics to engineering and environmental problems, 107-127.

Jonassen, H. 1957: Bidrag til Filsøegnens naturhistorie. Meddelser fra Dansk Geologisk Forening 13, 192-205.

Krog, H. 1979: Late Pleistocene and Holocene shorelines in Western Denmark. In Oele, E., Schuttelhelm, R.T. E. \& Wiggers, A. J. (Eds) The Quarternary History of the North Sea. Uppsala, Acta Universitatis Upsaliensis, 49. 83.

Massari, E. \& Parea, G. G., 1988: Progradational gravel beach sequences in a moderate to high-energy, micro-tidal marine environment. Sedimentology 35 881-913.

Mertz, E. L. 1924: Oversigt over de Sen- og Postglaciale Niveauforandringer i Danmark. Danmarks Geologiske Undersøgelse, 11 række, $41,50 \mathrm{pp}$.

Mörner, N. A. 1971: Eustatic changes during the last 20000 years and a method for separating the isostatic and eustatic factors in an uplifted area. Palaeogeography, Palaeoclimatology, Palaeoecology 9, 153-181.
Mörner, N. A. 1976: Eustatic changes during the last 8000 years in view of radiocarbon calibration and new information from the Kattegatt region and other north-western European coastal areas. Palaeogeography, Palaeoclimatology, Palaeoecology 19, 6385 .

Mörner, N. A. 1980: The northwest European 'Sea-level Laboratory' and Regional Holocene Isostasy. Palaeogeography, Palaeoclimatology, Palaeoecology 29, 281-300.

Nielsen, S. T. 1993: Sedimentology and Georadaranalysis of a Progradational Holocene Barrier Coast, Western Jutland, Denmark. Unpublished Cand. Scient thesis, 117 pp.

Nielsen, L. H, Johannessen, P. N. \& Surlyk, F. 1988: A Late pleistocene coarse-grained spit platform sequence in northern Jylland, Denmark. Sedimentology 35, 915-937.

Nielsen, J. \& Nielsen, N. 1990: Kystmorfologi. Geografforlaget, $185 \mathrm{pp}$.

Odgaard, B. 1985: Notat om Filsø. J. nr. Danmarks Geologiske Unders øgelse, 4413-11, 1-7.

Orford, J. D., Carter, R. W. G. \& Jennings, S. C. 1991: Coarse clastic barrier environments: Evolution and implications for Quarternary sea level interpretation. Quarternary International 9, 87-104.

Petersen, K. S. 1985: Det sydfynske arkipelag. Dets geologiske udvikling med sarlig hensyntagen til havniveauændringer og den marine molluskfauna. Særtryk fra Jørgen Skaarup: Yngre stenalder på øerne syd for Fyn. Meddelser fra Langelands Museum 1985 (Rudkøbing), 15-27.

Petersen, K.S. 1991: Holocene Coastal and Faunal Development of the Skagen Odde, Northern Jutland, Denmark. Quartemary International 9, 53-60.

Ribe Amtskommune, Miljøministeriet, Danmarks Geologiske Undersøgelse \& Skov- og Naturstyrelsen 1989. Redegørelse om muligheden for indvinding af ral og sand $i$ Vejers-området. Råstofindvinding, $54 \mathrm{pp}$.

Shennan, I. 1992: Holocene Sea-level Changes in the North Sea Region. In Tooley, M. J. \& Shennan, I (Eds) Sealevel changes. Basil Blackwell, Oxford, 109-151.

Smith, D. G. \& Jol, H. M. 1992: GRP results used to infer depositional processes of coastal spits in large lakes. In Hänninen, P. \& Autio, S. (Eds) Fourth International Conference on Ground Penetrating Radar, Rovaniemi, Finland. Geological Survey of Finland, Special Paper 16, $169-$ 177.

Suadicani, H. 1985: Nationale geologiske interesseområder, Filsø-Blåbjerg, 1-11.

Stuiver, M. \& Pearson, G. W. 1993: High-Precision Calibration of the Radiocarbon Time Scale, A.D. 1950-500 B.C. and 2500-6000 B.C. Radiocarbon 35, 1-25.

Tanner, W. F 1993: An 8000-year record of sea-level change from grain-size parameters: data from beach ridges in Denmark. The Holocene 3, 220-231.

Ulriksen, C. P. F 1982: Application of Impulse Radar to Civil Engineering, Unpublished Ph.D. thesis. Department of Engineering Geology, Lund University of Technology, Sweden (republished by Geophysical Survey Systems, Inc., N. Salem, N.H., U.S.A.), 175 pp. 